\title{
Low avidity antibodies to dsDNA as a diagnostic too
}

\author{
J C NOSSENT, ${ }^{1}$ V HUYSEN, ${ }^{2} \mathrm{R}$ J T SMEENK, ${ }^{2}$ AND A J G SWAAK ${ }^{1}$
}

From the ' Dr Daniel den Hoed Clinic, Department of Rheumatology, Groene Hilledijk 301, 3075 E命 Rotterdam, The Netherlands; and the ${ }^{2}$ Central Laboratory of the Netherlands Red Cross Blood Transfusion Service, Department of Autoimmune Diseases, Plesmanlaan 121, 1066 CX Amsterdam, The Netherlandiूs

SUMmaRY An evaluation of the diagnostic value of low avidity antibodies to double strande $\overrightarrow{\omega^{2}}$ DNA (dsDNA) measured by the polyethylene glycol (PEG) assay was undertaken. By routine screening low avidity anti-dsNDA were detected in the serum samples of 106 hitherto unknown patients. Clinical data of these patients were collected and when only low avidity anti-dsDN ${ }^{\circ}$ was present $(\mathrm{n}=92)$ a varied disease spectrum was observed. A diagnosis of systemic lupus erythematosus (SLE) was established in 48/92 (52\%), lupus-like disease in $21 / 92(23 \%)$ autoimmune hepatitis in $9 / 92(10 \%)$, rheumatoid arthritis in $8 / 92(9 \%)$, and mixed connective tissue disease in 2/92 (2\%) of all patients. Patients with definite SLE were all older than 45 years and predominantly female $(46 / 48,96 \%)$. They showed a remarkably low incidence of renaw disease $(2 / 69,3 \%)$. When high avidity antibodies to dsDNA as measured by the Farr assay were़े present as well $(n=14)$ a diagnosis of SLE could be established in $12 / 14(86 \%)$ of all patients $\frac{3}{\circ}$ indicating the secondary importance of low avidity anti-dsDNA in these patients.

Antibodies to double stranded DNA (dsDNA) are thought to play a part in the pathogenesis of systemic lupus erythematosus (SLE) ${ }^{1-3}$ The precise mechanism by which they contribute to tissue damage is a subject of discussion. Deposits of circulating immune complexes ${ }^{4-6}$ and in situ formation of dsDNA/anti-dsDNA ${ }^{7-10}$ immune complexes always seemed valid explanations, but anti-dsDNA antibodies are heterogeneous and differ with respect to (sub)class, specificity, complement fixing ability, and avidity. ${ }^{11} 12$

Nowadays, there are several methods of detecting antibodies to dsDNA. ${ }^{13} 14$ The main difference between such assays lies in their ability to detect antibodies to dsDNA with varying degrees of avidity. ${ }^{15}$

A clear relation has repeatedly been shown between high avidity antibodies detected by the Farr assay and disease activity. ${ }^{16-18}$ The role of low avidity antibodies has remained relatively uncertain, ${ }^{19}$ some reports showing a relation with a less fulminant form of SLE. ${ }^{20}$ Therefore we undertook a study to evaluate the diagnostic significance of low avidity antibodies to dsDNA.

Accepted for publication 27 January 1989.

Correspondence to Dr J C Nossent, Dr Daniel den Hoed Clinic, Department of Rheumatology, PO Box 5201, 3008 AE Rotterdam, The Netherlands.

\section{Patients and methods}

SERUM SAMPLES/PATIENTS

From 1 January 1986 until 31 December 1987, ever serum sample sent to the central laboratory foo routine testing of anti-dsDNA that showed positive fluorescence by the Crithidia luciliae test wa@ routinely tested in the polyethylene glycol (PEG) and Farr assays. When a positive test was observe in the PEG assay the attending physician was asked. to provide clinical information about the patient $b$ means of a questionnaire containing specific ques:tions pertinent to symptoms of rheumatic diseases whenever possible the diagnosis was confirmed bi clinical record investigation. During this period $37 \notin$ serum samples of new patients were found positive on immunofluorescence test screening; 106 of these samples were positive on subsequent testing in the PEG assay, and this group was the subject of our. study.

We divided patients into two groups: group $\mathrm{N}$ $(n=92)$, patients whose serum samples showed antif dsDNA antibodies only in the PEG assay $\left(>10^{\text {t }}\right.$ $\mathrm{U} / \mathrm{ml})$ and group II $(\mathrm{n}=14)$, patients whose serum samples were positive $(>10 \mathrm{U} / \mathrm{ml})$ in both PEG and Farr assays.

Patients fulfilling four or more American Rheu: matism Association (ARA) criteria for $\mathrm{SLE}^{3}$ werל considered to have definite SLE, while patient 
fulfilling three ARA criteria for SLE were diagnosed as having lupus-like disease. Rheumatoid arthritis was considered present in patients with five or more ARA criteria ${ }^{21}$ for rheumatoid arthritis (definite rheumatoid arthritis), whereas autoimmune hepatitis was diagnosed on evidence of hepatitis without viral cause and the presence of antibodies to smooth muscle or mitochondria, or both.

\section{CRITHIDIA LUCILIAE}

\section{IMMUNOFLUORESCENCE TEST}

Details of this immunofluorescence test have been published. ${ }^{22}$ Crithidia luciliae were grown, harvested, and used as described. Serum samples were diluted 1:10 in phosphate buffered saline (PBS; $0 \cdot 14$

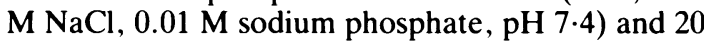
$\mu l$ of such a dilution was incubated for 30 minutes at room temperature on a spot of $C$ luciliae. After washing the slide for 30 minutes in PBS $0.5 \mathrm{ml}$ of fluorescein isothiocyanate conjugated anti-immunoglobulin (batch No SH 17-1-F9; dilution 1:50) was layered over the slide, followed by incubation for 30 minutes at room temperature. The slide was again washed with PBS and mounted, using a solution of $65 \%(\mathrm{w} / \mathrm{v})$ sucrose in PBS $\mathrm{pH} 8.0$, in which $0.5 \mu \mathrm{g} / \mathrm{ml}$ propidium iodide (Calbiochem) was dissolved. Fluorescence of the kinetoplasts was considered to indicate anti-dsDNA activity. The propidium iodide acts as a counterstain enabling localisation of the kinetoplasts. A KP-560 barrier filter was used to separate propidium iodide fluorescence from that of fluorescein isothiocyanate.

\section{PEG ASSAY}

Details of the PEG assay have been described. ${ }^{13}$ To $50 \mu \mathrm{l}$ of a dilution of serum, $50 \mu \mathrm{l}$ of a solution of 1.6 $\mathrm{mg} / \mathrm{ml}$ normal human gammaglobulin, $50 \mu \mathrm{l}$ of a solution of $0.2 \mathrm{mg} / \mathrm{ml}$ dextran sulphate (Pharmacia Fine Chemicals AB, Uppsala, Sweden, lot No 5259), $200 \mu \mathrm{l}$ of $7 \%$ (w/v) PEG (mol.wt 6000; KochLight Laboratories, Colnbrook, UK), and $50 \mu \mathrm{l}$ of a solution of $2 \mu \mathrm{g} / \mathrm{ml}\left[{ }^{3} \mathrm{H}\right]-P M 2-D N A$ (pseudomonal bacteriophage; specific activity $40-60 \times 10^{3} \mathrm{dpm} / \mu \mathrm{g}$ DNA) were added, forming an incubation volume of $400 \mu \mathrm{l}$. All components were dissolved or diluted in PBS.

The incubation was carried out at $37^{\circ} \mathrm{C}$ for one hour, followed by a two hour incubation at $4^{\circ} \mathrm{C}$. The mixture was then centrifuged for 15 minutes at 4000 $\mathrm{rpm}$ in a Hettich Rotanta/K centrifuge $(2500 \mathrm{~g})$. The radioactivity in $200 \mu \mathrm{l}$ of the supernatant was measured after addition of $10 \mathrm{ml}$ of NE- $260_{\text {SP }}$ (New England Nuclear Corp, USA). A ' $0 \%$ binding' control, in which serum was omitted, was included in each experiment. Anti-DNA activity was expressed in $\mathrm{U} / \mathrm{ml}$ instead of percentage binding. A sample contained one unit of anti-DNA if it bound $30 \%$ of $100 \mathrm{ng}$ PM2-DNA under the conditions described above.

F A R R A S S A Y

The Farr assay was performed as described by Aarden. ${ }^{14}$ To $100 \mu \mathrm{l}$ of the appropriate serum dilution was added $50 \mu \mathrm{l}$ of a solution of $16 \mathrm{mg} / \mathrm{ml}$ normal human gammaglobulin and $50 \mu \mathrm{l}$ of a solution of $\left.2 \mu \mathrm{g} / \mathrm{ml} \mathrm{[}{ }^{3} \mathrm{H}\right]-P M 2-D N A$. All components were dissolved or diluted in PBS.

After incubation of the mixture for one hour at $37^{\circ} \mathrm{C} 5 \mathrm{ml}$ of a cold $50 \%$ saturated ammonium sulphate solution was added. The precipitate was allowed to form for 30 minutes at $4^{\circ} \mathrm{C}$, after which it was pelleted by centrifugation for 15 minutes at 3000 g. The precipitate was washed twice with $50 \%$ saturated ammonium sulphate and, finally, dissolved in $1 \mathrm{ml}$ of Soluene-100 (Packard). After addition of $10 \mathrm{ml}$ scintillation fluid (Instafluor 11, Packard) the radioactivity was measured. The mean (SD) binding of 150 normal control sera was $5(3) \%$. Units are defined as stated under the PEG assay.

A NTI - D N A A VIDITY

As antibodies to ds-DNA vary widely in their avidity towards DNA we used two assays to discriminate between patients on the basis of their anti-DNA avidity. As has been shown before the Farr assay is strictly selective for high avidity anti-DNA, whereas the PEG assay allows for the simultaneous measurement of low and high avidity anti-DNA. ${ }^{23}{ }^{24}$ In fact, antibodies of the highest avidity are missed by the PEG assay because such antibodies tend to form rather small DNA/anti-DNA complexes, which are not precipitated by $3.5 \%$ PEG. ${ }^{15}$

\section{S T A T IS T I C S}

Statistical testing of data was performed with Student's $t$ test for mean values and with $\chi^{2}$ testing (with Yates's correction) for absolute numbers; a resulting $p$ value $<0.05$ was considered significant. Values are expressed as means (SD).

Table 1 Number of patients whose serum samples were positive on anti-dsDNA testing by various assays

\begin{tabular}{|c|c|c|}
\hline Assay & No $(\%)$ & positive \\
\hline Positive on immunofluorescence testing & 376 & $(100)$ \\
\hline Positive in Farr assay only & 270 & (72) \\
\hline Positive in $\mathrm{PEG}^{*}$ assay only & 92 & (24) \\
\hline Positive in Farr and PEG assays & 14 & (4) \\
\hline
\end{tabular}

*PEG=polyethylene glycol. 
Table 2 Diagnosis and demographic features of patients in groups $I$ and $I I^{*}$

\begin{tabular}{|c|c|c|c|c|}
\hline \multirow[b]{3}{*}{$\begin{array}{l}\text { Definite SLE } \nmid \ddagger \\
\text { Mean (SL) age at diagnosis (years) }\end{array}$} & \multicolumn{2}{|c|}{ Group I $(n=92)$} & \multicolumn{2}{|c|}{ Group II $(n=14)$} \\
\hline & \multirow{2}{*}{$\begin{array}{l}\begin{array}{l}\text { No of female } \\
\text { patients }(\%)\end{array} \\
46(50) \\
46 \cdot 9(16 \cdot 3)\end{array}$} & \multirow{2}{*}{$\begin{array}{l}\begin{array}{l}\text { No of male } \\
\text { patients }(\%)\end{array} \\
2(2) \\
75 \cdot 5(1 \cdot 5)\end{array}$} & $\begin{array}{l}\text { No of female } \\
\text { patients (\%) }\end{array}$ & $\begin{array}{l}\text { No of male } \\
\text { patients (\%) }\end{array}$ \\
\hline & & & $\begin{array}{c}7 \quad(50) \\
30 \cdot 7(13 \cdot 9)\end{array}$ & $\begin{array}{c}5 \\
35 \cdot 7(36) \\
(20 \cdot 4)\end{array}$ \\
\hline $\begin{array}{l}\text { Lupus-like disease } \dagger \\
\text { Mean (SD) age at diagnosis (years) }\end{array}$ & $\begin{array}{l}20(22) \\
52 \cdot 9(21 \cdot 1)\end{array}$ & $\underset{34 \cdot 0}{1}(1)$ & 0 & 0 \\
\hline $\begin{array}{l}\text { Autoimmune hepatitis } \ddagger \\
\text { Mean (SD) age at diagnosis (years) }\end{array}$ & $\begin{array}{l}9 \\
61 \cdot 8(10) \\
6(19 \cdot 5)\end{array}$ & 0 & 0 & 0 \\
\hline $\begin{array}{l}\text { Rheumatoid arthritis } \dagger \\
\text { Mean (SD) age at diagnosis (years) }\end{array}$ & $\begin{array}{cc}8 & (9) \\
48 \cdot 7(14 \cdot 8)\end{array}$ & 0 & 0 & 0 \\
\hline $\begin{array}{l}\text { MCTD } \ddagger \\
\text { Mean (SD) age at diagnosis (years) }\end{array}$ & $\begin{array}{cl}2 & (2) \\
51 \cdot 5 & (2 \cdot 5)\end{array}$ & 0 & 0 & 0 \\
\hline $\begin{array}{l}\text { Miscellaneous } \\
\text { Mean (SD) age at diagnosis (years) }\end{array}$ & $\begin{array}{cc}3 & (3) \\
54 \cdot 6 & (29 \cdot 6)\end{array}$ & $\underset{69 \cdot 0}{1}(1)$ & $\begin{array}{c}1 \\
35 \cdot 0\end{array}$ & $\begin{array}{c}1 \\
37 \cdot 0\end{array}$ \\
\hline Total No of patients & $88 \quad(96)$ & $4 \quad(4)$ & $8 \quad(57)$ & $6 \quad(43)$ \\
\hline
\end{tabular}

Group I=patients whose serum samples showed anti-dsDNA antibodies only in the PEG assay $(>10 \mathrm{U} / \mathrm{ml})$; group $\mathrm{II}=$ patients whose $\frac{\overrightarrow{\mathrm{D}}}{\mathrm{D}}$ serum samples were positive $(>10 \mathrm{U} / \mathrm{ml})$ in both PEG and Farr assays.

$\dagger p<0.01$ for number of patients in group I and group II.

$\ddagger$ SLE = systemic lupus erythematosus; $M C T D=$ mixed connective tissue disease.

\section{Results}

S ER U M S A M PLES

In the two year study period we found 376 serum samples positive on immunofluoresence testing for anti-dsDNA; these samples were all sent for diagnostic testing (Table 1). Upon subsequent testing 106 serum samples $(28 \%)$ were positive in the PEG assay; 92 of these samples were positive in the PEG assay only, while 14 gave positive results in both Farr and PEG assays. Two hundred and seventy (72\%) serum samples gave positive results in the Farr assay only; they were not studied further as our interest lay with the PEG positive sera, and the significance of Farr positive sera is well established. ${ }^{16-19}$

DIAGNOSIS AND DEMOGRAPHIC FEATURES Table 2 shows diagnosis and demographic features of patients in both groups. A definite diagnosis of SLE was made in $12 / 14(86 \%)$ of group II patients and in only $48 / 92(52 \%)$ of group I patients $\left(\chi^{2}=3 \cdot 12 ; p<0 \cdot 002\right)$. No other definite diagnosis was established in group II patients, while the remaining group I patients showed a varied pattern of autoimmune diseases, including lupus-like syndrome in $21 / 92(23 \%)$, autoimmune hepatitis in $9 / 92$
$(10 \%)$, and rheumatoid arthritis in $8 / 92(9 \%)$. Sex differences were striking, with a female prepondero ance $(88 / 96,96 \%)$ in group I patients compared with group II patients $(8 / 14,57 \%)\left(\chi^{2}=19.75 ; p<0.001\right) \stackrel{\circ}{\circ}$ Age at the moment of diagnosis was similar for maleo and female patients with SLE in group II, whereas male group I patients with SLE were older than the women in this group $(\mathrm{p}<0.001)$. Group I patients. with SLE (male and female) were significantly oldee巳 than group II patients with SLE $(p<0 \cdot 05)$.

\section{DISEASE MANIFESTATIONS}

When only patients with definite SLE and lupus-like disease were considered $(81 / 106,76.4 \%$ of als patients) a very low rate of renal disease was observed in group I patients $(p<0.001)$, while othe disease manifestations did not differ between the two groups (Table 3).

ANTI-dSDNA TITRES

Figure 1 shows anti-dsDNA values by PEG assay for group I patients. Lower titres were found foo patients with lupus-like disease (mean (SD) 41 . (23.2) $\mathrm{U} / \mathrm{ml}$ ) and mixed connective tissue diseas (mean (SD) 13.0 (19.2) U/ml) than for patients with SLE, whereas patients with other diseases had similar titres. Levels of anti-dsDNA by PEG assa 
Table 3 Disease manifestations in patients with definite systemic lupus erythematosus and lupus-like disease

\begin{tabular}{lcl}
\hline Disease & $\begin{array}{l}\text { Group If } \\
(n=69) \\
\text { No (\%) }\end{array}$ & $\begin{array}{l}\text { Group II } \\
(n=12) \\
\text { No (\%) }\end{array}$ \\
\hline Arthritis & $52(75)$ & $7(58)$ NS \\
Skin abnormalities & $29(42)$ & $4(33)$ NS \\
Serositis & $13(19)$ & $4(33)$ NS \\
Nephritis & $2(3)$ & $5(42) *$ \\
CNS manifestations & $11(16)$ & $1(8)$ NS \\
Haemolytic anaemia & $4(6)$ & $1(8)$ NS \\
Leucocytopenia & $14(20)$ & $3(25)$ NS \\
Thrombocytopenia & $12(17)$ & $3(25)$ NS \\
\hline
\end{tabular}

$* \mathrm{p}<0.001$.

†CNS=central nervous system.

¥For description of groups see Table 2 .

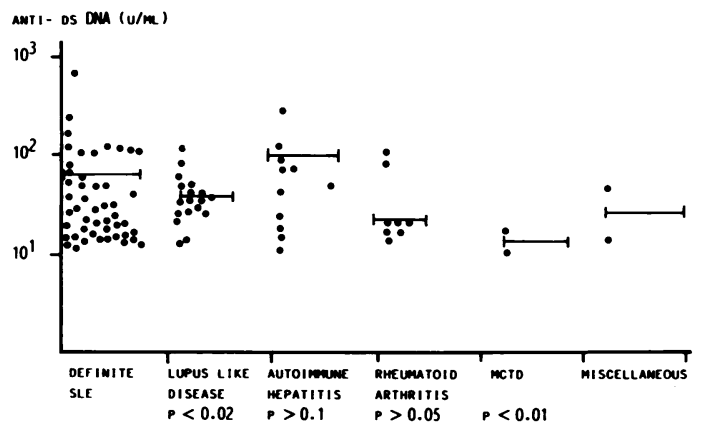

Fig. 1 Anti-dsDNA levels in the polyethylene glycol assay divided by the various diagnoses in group I; $p$ value indicates difference from patients with definite systemic lupus erythematosus (bars indicate group mean). $S L E=$ systemic lupus erythematosus; $M C T D=$ mixed connective tissue disease.

in group II patients with SLE (mean (SD) $111 \cdot 2$ (105) $\mathrm{U} / \mathrm{ml}$ did not differ from levels in group I patients with SLE (mean (SD) 85.4 (117) U/ml), whereas anti-dsDNA levels by Farr assay in group II patients with SLE were higher (1053 (1985) U/ml) than those in the PEG assay of these patients $(0.05<\mathrm{p}<0.1)$.

\section{Discussion}

Previous experience has taught us that a significant number of patients' serum samples on testing for anti-dsDNA show a positive fluorescence in the Crithidia test but are negative upon subsequent analysis in the Farr assay. This discrepancy is explained by the fact that these patients have antibodies to dsDNA of low avidity, which are dissociated from
DNA by the high salt concentration used in the Farr assay to precipitate DNA/anti-DNA complexes. ${ }^{23}$ Such antibodies can, however, be detected by the PEG assay, which is in fact a modified Farr assay, in which ammonium sulphate precipitation is replaced by polyethylene glycol precipitation.

High avidity antibodies, which are not dissociated in the Farr assay, have been shown to be specific for SLE ${ }^{16-19}$ and are now one of the criteria on which the diagnosis SLE can be based. ${ }^{3}$ The significance of low avidity antibodies to dsDNA is less clear.

In this study the diagnostic value of low density antibodies to dsDNA was analysed. When patients' serum samples contained high and low avidity antibodies (group II) a diagnosis of SLE could be made in $12 / 14(86 \%)$ of the patients. This confirms the value of the Farr assay for diagnosing SLE, and thus the PEG assay has little additional value in these patients. When only low avidity antibodies were present, however, a much more diverse spectrum of diseases was observed: definite SLE in 48/92 (52\%) and lupus-like disease (three ARA criteria) in $21 / 92(23 \%)$ of all patients; autoimmune hepatitis in $9 / 92(10 \%)$; rheumatoid arthritis in 8/92 $(9 \%)$; and mixed connective tissue disease in $2 / 92$ $(2 \%)$. From this we conclude that there is an intermediate specificity of low avidity anti-dsDNA for SLE. When patients with SLE from both groups were compared, however, it was clear that patients with only low avidity anti-dsDNA had significantly less signs of renal involvement. Although early reports correlated the presence of low avidity antidsDNA with earlier onset and increased severity of lupus nephritis in mice and humans, ${ }^{25}$ our results support the later reports that lupus nephritis in man is mainly associated with high avidity antibodies to dsDNA. 202627

We found little correlation between titres of low avidity antibodies to dsDNA and the different diseases. Patients with lupus-like disease (a prodrome or a mitigated form of SLE?) and mixed connective tissue disease had lower values, and although no definite conclusion can be drawn from these data, it seems that the low avidity character of anti-dsDNA, rather than its level, is important in the diagnosis.

In conclusion, we studied the diagnostic value of low avidity antibodies to dsDNA and our results indicate that when only low avidity antibodies to dsDNA are found a spectrum of autoimmune disease is present and SLE can be diagnosed in about $50 \%$ of these patients. These patients which SLE are all elderly ( $>45$ years) and predominantly female $(95 \%)$, and they have a remarkably low incidence of renal disease. When high avidity antibodies are present as well a diagnosis of SLE can 
be made in $86 \%$ of the cases, leaving only a minor role for low avidity antibodies to dsDNA in this setting.

We wish to thank Mrs T van Vlijmen for preparing this paper.

\section{References}

1 Tan E M, Schur P H. Carr R I, Kinkel H G. DNA and antibodies to DNA in serum of patients with SLE. $J$ Clin Invest 1966; 45: 1732-40.

2 Stollar D B. Nucleic acid antigens. In: Sela M, ed. The antigens. Vol 1. New York: Academic Press, 1973: 1-85

3 Tan E M, Cohen A S, Fries J F, et al. The revised criteria for the classification of SLE. Arthritis Rheum 1982; 25: 1271-7.

4 Bruneau Ch, Beneviste J. Circulating DNA-anti-DNA complexes. J Clin Invest 1979; 64: 191-8.

5 Koffler D, Agnello V. Tholomn R. Kinkel H G. SLE-prototype of immune complex nephritis in man. $J$ Exp Med 1971: 134: $169-79$.

6 Landry P H. Saur M W. SLE: studies of antibodies bound to skin. J Clin Invest 1973: 52: 1871-80.

7 Tan E. Auto-antibodies to nuclear antigens. Adv Immunol 1982; 33: $167-240$.

8 Gavalchin J, Nicklas J A. Eastcott J W. Lupus prone mice produce potentially nephritogenic autoantibodies. J Immunol 1985; 134: 885-94.

9 Theofilopoulos A N, Dixon F J. Murine models of SLE. Adv Immunol 1985; 37: 269-390.

10 Faaber P. Rijke G P M, Smeenk R J T, Capel P J A. van de Putte L B A, Berden J H M. Cross-reactivity of anti-DNA antibodies: A new clue for the pathogenesis of SLE? In: Peeters $\mathrm{H}$, ed. Protides of the biological fluids. New York: Pergamon Press, 1985: 305-8

11 Ballou S P, Kushner I. Immunochemical characteristics of antiDNA antibodies in patients with active SLE. J Clin Exp Immunol 1979; 37: 58-67.

12 Halliday G M. Salaman M R. Seifert M H. Johnson K J. Malcolm D B. Evaluation of ELISA system for determination of anti-DNA antibodies. Ann Rheum Dis 1985: 44: 507-13.
13 Smeenk R, Lely van de G. Aarden L. Avidity of antibodies t dsDNA. J Immunol 1982: 128: 73-8.

14 Aarden L A. Measurement of anti-DNA antibodies. Ant? Rheum Dis 1977: 36 (suppl): 1-5.

15 Smeenk R. A comparison of four different anti-DNA assay In: Pal S B, ed. Immunoassay techniques. Vol 2. Berlin: क्ष Gruyter, 1986: 145-66.

16 Swaak A J G, Aarden L A, Statius van Eps L W. Feltkamp T W. Anti-dsDNA and complement profiles as prognostic guide in SLE. Arthritis Rheum 1979; 22: 226-35.

17 Swaak A J G. Groenwold J. Aarden L A. Statius van Eps L du Feltkamp T E W. Prognostic value of anti-dsDNA in SLE. Ann Rheum Dis 1982: 41: 388-95.

18 Swaak A J G, Smeenk R J T. Detection of anti-dsDNA as: diagnostic tool. Ann Rheum Dis 1985; 44: 245-51.

19 McGrath H. Biundo J. A longitudinal study of high and $10 \omega$ avidity antibodies to dsDNA in SLE. Arthritis Rheum 1985; 28 425-30.

20 Smeenk R J T, van Rooyen A, Swaak A J G. Dissociatiof studies of DNA/anti-dsDNA complexes in relation to thed avidity. J Immunol Methods 1988; 109: 27-35.

21 Ropes M W. Bennett G A. Cobb S. Jacox R. Jessar R A Revision of diagnostic criteria for rheumatoid arthritis. Anil Rheum Dis 1959; 18: 49-53

22 Aarden L. Smeenk R. Measurements of antibodies specific fon DNA In: Lefkovits I. Pernis B. eds. Immunological methods. Vol II. New York: Academic Press. 1981: 75-82.

23 Smeenk R J T. Low avidity antibodies to dsDNA. Amsterdar 1982: 183-99. (PhD thesis.)

24 Smeenk R J T. Brinkman K, van den Brink H, Westgeest Reaction patterns of monoclonal antibodies to DNA.J Immun\& 1988; 140: 3786-92.

25 Steward M W. Katz F E. West N J. Role of low afe antibody in immune complex disease. Clin Exp Immunol 21: $121-30$.

26 Steward M W. Glass D N. Maini R N, Scott J T. Role of avidity anti-DNA in human and murine lupus syndrone. Rheumatol 1974: 1: 75-6.

27 Winfield J B, Faiferman I. Koffler D. Avidity of anti-DNA serum and glomerular eluates from patients with SLE. $J$ Clo Invest 1977: 59: 90-6. 